\title{
The Faroese Path to a Comprehensive Education System
}

\author{
Nina Volckmar
}

\begin{abstract}
This article traces the Faroese path to a comprehensive education system, following the winding road from Norwegian heritage to Danish rule and an increasing degree of autonomy. The main research question explores the extent to which the Faroese themselves have determined the development of their education system, and the extent to which Norwegian and most of all Danish influences have been crucial in this process. Previous research on the development of Faroese education is insufficient and few secondary sources are available. Therefore, this article is largely based on primary sources, such as legislation, curricula, circulars, official reports and interviews. The analysis shows that changes in governance structures and economic conditions are determinant factors that have had impact on the extent to which the Faroese have been responsible for their own educational development. Strong economic growth in recent years has allowed the Faroe Islands to adopt what is considered to be "global education" and "international standards."
\end{abstract}

Keywords • Faroe Islands, self-government, comprehensive education, educational development, policy diffusion, policy borrowing

\section{Introduction}

The Faroe Islands were under Norwegian rule from around the eleventh century until 1814. However, when in 1397 the Kingdom of Norway entered the Kalmar Union with Denmark, Denmark gradually took over control of the islands. In accordance with the Kiel-Treaty of 1814, Denmark had to surrender Norway to Sweden, while the Faroe Islands remained under Danish Rule. The islands continued to be a Danish territory until 1948 when the Home Rule Act came into force. ${ }^{1}$ Since then, the Faroe Islands have been a self-governing entity within the Danish Kingdom, taking over the administration and governance of affairs and fields of interest considered to be special Faroese matters, as itemised in an accompanying List A. In this process, the Faroe Islands established their own legislative assembly (Løgting) and their own Faroese government (Landsstýri). ${ }^{2}$

1 The Government of the Faroe Islands, "Home Rule Act of the Faroe Islands 1948." http://www.government.fo/the-government/the-home-rule-act/.

2 Ibid. See also Jón Th. Thór, Jóan Pauli Joensen and Daniel Thorleifsen, "Nationalisme og nationsdannelse i 1800- og 1900-tallet," in Naboer i Nordatlanten: Forøerne, Island og Grønland, ed. Jon Th. Thór, Daniel Thorleifsen, Andras Mortensen, and Ole Marquardt (Tórshavn: Faroe University Press, 2012), 395-465, especially page 429. At the same time, the earlier Danish amtmand was replaced by a rigsombudmand.

Nina Volckmar is Professor at the Department of Education and Lifelong Learning, Norwegian University of Science and Technology, NTNU.

Email:nina.volckmar@ntnu.no

In order to maintain the integrity of the peer review process, senior editor Henrik Åström Elmersjö has mediated the contacts between the author (who is one of the editors for this issue) and the reviewers of this article. 
The Home Rule Act of 1948 listed education as one of the Faroese special fields of interest. ${ }^{3}$ However, the Faroese government decided to treat education as a shared responsibility between Denmark and the Faroe Islands, mostly due to financial considerations. At that time, the Faroe Islands had neither the financial resources nor the civil servants to take full responsibility for their inhabitants' education. The Home Rule Act declared that Faroese was to be the main language in school, and Faroese was the first language in all primary schools (Fólkaskúli). Gradually, the Faroe Islands have been able to take responsibility for the development of Faroese education. ${ }^{4}$ In 2005, the Takeover Act replaced the Home Rule Act, which made it possible for the Faroese authorities to take over the responsibility for all affairs with the exception of state administration, citizenship, the Supreme Court and defence policy, as well as monetary issues and monetary policy. ${ }^{5}$ Today, the Faroe Islands are experiencing economic recovery after severe economic crises.

Based on this winding path to full Faroese responsibility for education, I find it interesting to look at the development of Faroese education, tracing Faroese, Norwegian and Danish influences, directives and control. The main research question explores the extent to which the Faroese themselves have determined the development of their education system and the extent to which Norwegian and most of all Danish influences have been crucial in this process.

As a Norwegian researcher in the field of the history of education, I see this article as a first step in establishing Faroese educational history and education policy as a topic for research in the Faroe Islands.

\section{Sources}

There is one detailed main source on the development of Faroese education at the national level, Skole på Forøerne i 1000 år: En skolehistorisk håndbok [School in the Faroe Islands for 1000 years: A school history manual]. It is written in Danish by Ludvig Petersen. ${ }^{6}$ His background includes being a teacher, school inspector and school consultant in rural areas, and eventually he became the administrative head of teaching in the Faroe Islands from 1979 to 1985 . His book is still in use in teacher education. Thus, we have an insider's perspective on the system serving as the main source on the development of Faroese education. In the monumental five-volume work Dansk skolehistorie [Danish School History], all volumes have a section on education in the subordinated territories, such as Greenland, Iceland and the Faroe Islands. ${ }^{7}$ Similarly, the book Naboer i Nordatlanten: Hovedlinjer $i$ Vestnordens historie gennem 1000 år [Neighbours in the North Atlantic. Main lines in West Nordic

3 The Government of the Faroe Islands (1948).

4 Elin S. Jacobsen, Sigdriður Jörundsdóttir, and Daniel Thorleifsen, "Skole og uddannelse," in Naboer i Nordatlanten: Forøerne, Island og Grønland: Hovedlinjer $i$ Vestnordens historie gennom 1000 år, ed. Jón Th. Thór, Daniel Thorleifsen, Andras Mortensen and Ole Marquardt (Thórshavn: Faroe University Press, 2012), 297.

5 The Government of the Faroe Islands, “Takeover Act of the Faroe Islands 2005.” http://www.government.fo/foreign-relations/constitutional-status/the-takeover-act/

6 Ludvig Petersen, Skole på Forøerne i 1000 År: En skolehistorisk håndbog (Tórshavn: Published by the author in cooperation with Selskapet for Dansk Skolehistorie og Føroya Lærarskúla, 1994).

7 Charlotte Appel and Ning de Coninck-Smith, eds., Dansk Skolehistorie, Vol 1-5. (Aarhus: Aarhus Universitetsforlag, 2013-2015). 
history over 1000 years] also gives an overview of school and education in Greenland, Iceland and the Faroe Islands. ${ }^{8}$ The analysis of Faroese education in these two overview works is not especially in-depth, relying for the most part on the story told by Petersen. ${ }^{9}$ These sources are in Danish and accessible to Scandinavian researchers. I found no research overview in English, and to the best of my knowledge, there is no Faroese analysis or ongoing scholarly research on the development of Faroese education today. ${ }^{10}$ Neither the history of education nor education policy are topics at the University of the Faroe Islands. ${ }^{11}$

Apart from the sources accounted for above, my analysis of Faroese education is largely based on primary sources, such as legislation, curricula, circulars, reports from the Ministry of Education, Research and Culture, and interviews with staff or education officials. ${ }^{12}$ The first Faroese regulations on education and curricula were written in Danish (1845). From the 1990s, the legislation and curricula are in Faroese, making them hard, but not impossible to understand on a superficial level for a Norwegian, as Faroese is a West Nordic language derived from Old Norse and is closely related to Norwegian and Icelandic.

In this article I will first give an account of the development of Faroese education, and at the same time trace Faroese, Norwegian and Danish influences, directives and control. The structure follows the changes in the position of the Faroe Islands as a self-governing nation under the external sovereignty of the Kingdom of Denmark, and education up to 1814, education between 1814 and the Home Rule Act 1948, education between 1948 and the Takeover Act 2005 and finally education after 2005. I will also take coinciding political changes and economic cycles into consideration. Finally, I will discuss the extent to which the Faroese themselves have been in charge of the development of Faroese education and try to explain the challenges and impediments the Faroese have experienced due to the small size of the country and the relatively small number of inhabitants.

\section{Policy diffusion and policy borrowing}

Due to the lack of sources and explicit analysis of Faroese educational policy-making, there are hardly any references in the literature to offer conclusive proof of Danish, Norwegian and Faroese influences, directives and control. Nevertheless, the discussion in this article is based on some theories from the field of policy diffusion that are used in political science and public administration research, ${ }^{13}$ as well as the theory of policy borrowing in comparative educational research. ${ }^{14}$ Policy diffusion is

8 Jacobsen, Jörundsdóttir and Torleifsen (2012), 297-360.

9 Petersen (1994).

10 There is some research on Faroese teacher education.

11 University of the Faroes Islands, "University of the Faroe Islands," https://www.setur.fo/en/.

12 The interviewees have read and commented on earlier versions of my presentation of the development of Faroese education. However, as each of them has been involved in the administration of Faroese education in one way or another, their stories might be subjective.

13 Charles R. Shipan and Craig Volden, "Policy Diffusion: Seven Lessons for Scholars and Practitioners," Public Administration Review 72, no. 6 (2012).

14 Gita Steiner-Khamsi, "The Politics and Economics of Comparison," Comparative Education Review 54, no. 3 (2010); "Cross-National Policy Borrowing: Understanding Reception and Translation," Asia Pacific Journal of Education 34, no. 2 (2014); "Comparison and Context: The Interdisciplinary Approach to the Comparative Study of Education," Current Issues in Comparative Education 16, no. 
defined as one government's policy choices being influenced by the choices made by other governments. In this article, policy diffusion, seen as geographical clustering between neighbouring countries that share political, economic and demographic similarities, seems especially relevant in analysing the formative years of developing Faroese education during the twentieth century. ${ }^{15}$ Steiner-Khamsi, Professor of comparative and international education, distinguishes between normative and analytical directions within policy borrowing in education. The first direction uses comparison to identify best-performing educational systems from which lessons of "best practice" can be learned and transferred. In this article, I will rely on the second direction that analyses why and when such external references are made and examines the impact of such imports on existing policies and power constellations. ${ }^{16}$ Furthermore, Steiner-Khamsi's epidemiological model of global dissemination ${ }^{17}$ seems especially relevant for analysing the most recent changes in Faroese education in the context of a globalised educational ideology.

Additionally, the term "silent borrowing" might illuminate the obviously nonexplicit borrowing processes in Faroese educational policy-making. ${ }^{18}$

\section{Primary education \\ Up to the Kiel Treaty of 1814}

Publicly coordinated schooling in Denmark and Norway dates back to 1739-1742, when the Danish-Norwegian King Christian VI decreed that compulsory schooling was to be part of his state-controlled pietism and introduction of compulsory confirmation in 1736. To ensure that everyone had a sufficient basis for living in accordance with pietistic Lutheranism and qualify for confirmation, compulsory schooling was considered necessary for those who did not otherwise receive the necessary training. ${ }^{19}$ Because the Faroe Islands at that time were part of Norway and subject to Danish control, one would think that the same regulations applied to the Faroe Islands. However, the Faroese population was scattered over 17 different islands, and geographical and cultural differences, as well as a rudimentary transportation system, made governing from Denmark difficult. ${ }^{20}$ At this time, the Faroe Islands were very poor. Agriculture, hunting and fishing were the most important means of livelihood. ${ }^{21}$

2 (2014a); "New Directions in Policy Borrowing Research," Asia Pacific Education Review 17, no. 3 (2016); Florian Waldow, "Undeclared Imports: Silent Borrowing in Educational Policy-Making and Research in Sweden," Comparative Education 45, no. 4 (2009).

15 Shipan and Volden (2012).

16 Steiner-Khamsi (2014); (2016).

17 Steiner-Khamsi (2010).

18 Waldow (2009).

19 Gunn Imsen and Nina Volckmar, "The Norwegian School for All: Historical Emergence and Neoliberal Confrontation," in The Nordic Education Model: "A School for All" Encounters Neo-Liberal Policy, ed. Ulf Blossing, Gunn Imsen and Lejf Moss (Dordrecht: Springer Netherlands, 2014), 35.

20 Christian Larsen, Erik Nørr, and Pernille Sonne, Da skolen tog form: 1780-1850, Dansk Skolehistorie, ed. Charlotte Appel and Ning de Coninck-Smith, Vol. 2, (Aarhus: Aarhus Universitetsforlag, 2013).

21 Erland Viberg Joensen, Ole Marquardt and Jón Th. Thór, "Erhvervs- og næringsliv i tiden ca. 15501850," in Naboer i Nordatlanten: Forøerne, Island og Grønland: Hovedlinjer i Vestnordens historie gennom 1000 år, ed. Jon Th. Thór, Daniel Thorleifsen, Andras Mortensen, and Ole Marquardt (Tórshavn: Faroe University Press, 2012), 162-203. 
Around 1000, Norway introduced Christianity to the Faroe Islands and established an episcopal seat and a priest school in Kirkjubøur in the twelfth century. According to Petersen, ${ }^{22}$ this was the first real school in the Faroe Islands. There was also a school for monks in Tórshavn which was considered to be the first seed for the later Tórshavn Latin School that was established in the sixteenth century. The purpose of the school was mainly to educate ecclesiastical teachers and had little influence on ordinary people. ${ }^{23}$ From around 1000, parents taught their children what they deemed to be most necessary. ${ }^{24}$ As in Norway and Denmark, Christianity and moral upbringing were the main tasks in educating children. Gradually, a system of home education for children developed, most often an arrangement with ambulatory private teachers educated by the priests. Home education as such matched the rough geographical conditions in the Faroe Islands, its many islands and scattered population. Because the Faroe Islands did not have their own standardised written language until 1854, Danish became the language for church and school in the Faroe Islands and all textbooks were in Danish. Faroese was maintained as a spoken language. ${ }^{25}$

\section{Between 1814 and the Home Rule Act of 1948}

While Norway was surrendered to Sweden after the Kiel-Treaty in 1814, the Faroe Islands remained under Danish rule. At the same time, Denmark decided upon five new Comprehensive Education Acts stipulating that all children had to attend school from the age of seven until confirmation age. ${ }^{26}$ However, due to the many linguistic, cultural and geographical differences, the new Danish school structure of 1814 was difficult to implement in the Faroe Islands. As private initiatives were needed to set up schools, only Tórshavn had a peasantry school, established in 1806, and which later became Tórshavn Municipal School. The Faroese opposed a strict compulsory school system. In 1845, provisional regulations for the Faroese public school (Almueskole), which were almost as detailed as the Danish version, were approved by the Danish State. However, this approval led to a heated debate and opposition in the Faroe Islands. Even the incorporated home-education demolished. In 1854, the Faroese Education Act ensured that there was a permanent primary school in Tórshavn, and from 1861 also a Realschule. ${ }^{27}$ All along, the Faroese advocated the need to prepare their children for future Faroese work and opposed what they experienced as unnecessary schooling. Reading and religious upbringing were sufficient for children who outside of the home or smallholding would become fishermen and sailors. ${ }^{28}$ This seems to be an everlasting conflict in the Faroese educational debate, which is more prominent on the islands than in many other countries. In 1872, a new Municipality Act established statutory compulsory schooling (undervisningsplikt), however,

22 Petersen (1994).

23 Ibid.

24 Ibid.

25 Charlotte Appel and Morten Fink-Jensen, Da loereren holdt skole: Tiden før 1780, Dansk skolehistorie, ed. Charlotte Appel and Ning de Coninck-Smith, Vol. 1 (Aarhus: Aarhus Universitetsforlag, 2013).

26 Larsen, Nørr, and Sonne (2013).

27 Ibid.

28 Anne K. Gjerløff and Anette F. Jacobsen, Da skolen blev satt i system: 1850-1920, Dansk skolehistorie, ed. Charlotte Appel and Ning de Coninck-Smith, Vol. 3 (Aarhus: Aarhus Universitetsforlag, 2014). 
school attendance (skoleplikt) was not compulsory. The same was true in Denmark. Nevertheless, several public schools were eventually established on the islands, but their conditions were primitive. ${ }^{29}$

In 1912, a Royal directive laid down some guidelines for the Faroese curriculum. However, until the Education Act of 1962, there was no overarching curriculum for Faroese schools. Nevertheless, according to Petur Sigvardsen, ${ }^{30}$ schools across the country tended to use the same textbooks. Compared to other countries the Faroe Islands lagged far behind when it came to public schooling during the nineteenth century. ${ }^{31}$ The Education Act of 1854 and the Royal Directive of 1912 regulated schooling in the Faroe Islands until the Education Act of 1962. Home education still dominated in the rural areas. ${ }^{32}$

\section{Between 1948 and the Takeover Act of 2005}

As mentioned above, The Home Rule Act of 1948 listed education as a Faroese Special Responsibility. However, mostly due to the poor economic situation and the lack of civil servants, the Faroese government decided that education was to be a shared responsibility between Denmark and the Faroe Islands. ${ }^{33}$ In 1938, the Danish government decided to treat the Faroese and Danish languages equally in school. However, the Home Rule Act took a step further and declared that Faroese was the main language in school and that Faroese was to be the first language in all primary schools. Nevertheless, all the students should, and still have to learn Danish so that they can use it in administrative capacities. ${ }^{34}$

In the years after World War II, the Faroese heatedly debated their educational system. The demand for the provision of education after the age of 14 increased. A committee appointed in 1959 presented its report, Grøna Bók, in February 1960, which proposed new legislation for primary education. The Education Act of 1962 introduced a seven-year compulsory comprehensive school as the basis for further education, either in a three-year academic course qualifying for university, or years eight to nine (and optional ten) for those aiming for working life. ${ }^{35}$ At the same time, a national curriculum was prepared, with a schedule, list of subjects, themes for each subject, reading lists, teaching methods and teaching materials. ${ }^{36}$ While the curriculum was comprehensive and detailed for the first seven years (Brúna bók), the curriculum for the three-year academic course (realskole) still referred to the existing Danish curriculum as the examinations were on a par with the Danish ones. The

29 Petersen (1994); Anne K. Gjerløff et al., Da skolen blev sin egen: 1920-1970, Dansk Skolehistorie, ed. Charlotte Appel and Ning de Coninck-Smith, Vol. 3 (Aarhus: Aarhus Universitetsforlag, 2014).

30 Petur Jacob Sigvardsen. "Interview with Nina Volckmar" (March 7 and 9, 2017). Sigvardsen (1932-) began his career as a teacher and then served as a school inspector on the central school board in Torshavn from 1973, which became the Directorate for Education and Training in 1979. Sigvardsen retired in 1997.

31 Petersen (1994).

32 Larsen, Nørr, and Sonne (2013); Gjerløff and Jacobsen (2014).

33 The Government of the Faroe Islands (1948) http://www.government.fo/the-government/thehome-rule-act/; Gjerløff et al. (2014).

34 Arnfinnur Thomassen, Forøsk $i$ den forøske skole (Odense: Udgivelsesudvalgets samling af studenterafhandlinger, 1985).

35 Seven years of compulsory education was introduced in Denmark in 1814 and in Norway in 1936. 36 Petersen (1994). 
curriculum for years eight and nine were roughly sketched and limited due to the lack of experience with these school years. ${ }^{37}$

According to Petersen, ${ }^{38}$ the comprehensive curriculum from 1962 (Brúna bók) was completely new and together with the new Education Act of 1962, the year 1962 stands out as one of the most important moments in the history of the Faroese Fólkaskúli. The Education Act and the new curriculum resulted in equitable conditions for urban and rural areas. Moreover, large centrally placed school buildings, called "the yellow schools" because of their colour, replaced the small rural school buildings. The roads were improved, and the local communities collaborated on building schools for students in years eight and nine (ten). ${ }^{39}$

In 1968, a more thoroughly prepared curriculum for years eight and nine was published, bearing the name Gula Bók. The aim was to make these two school years equal with the academic course. According to Peterson, Gula Bók was extremely flexible and student-centred in the sense that the students could work on subjects within their own field of interest. In 1970, year ten was also given its own curriculum, Reyða Bók. In the following years, all schools or school districts established tenth year classes. ${ }^{40}$ In the years to come, the authorities built several new combined schools (years one to nine (ten)), as the old schools were too small and outdated.

How can we explain the introduction of a seven-year compulsory comprehensive school in the Faroe Islands as late as in 1962? The main explanation was that the Faroe Islands finally experienced economic growth that offered greater political latitude for educational development. Originally, agriculture, hunting and fishing were the most important livelihoods in the Faroe Islands, and until 1900, most people subsisted on sheep farming. However, during the nineteenth century, the fisheries emerged as the dominant industry in the Faroe Islands, and in the 1970s and 1980s this industry had very good years. ${ }^{41}$ I will come back to fisheries as an important explanatory factor later on in the article.

In 1970, the school board appointed a more permanent curriculum committee whose purpose was to continuously update the Fólkaskúla curriculum. The committee published 13 reports, where the second one, from 1972, was the most revolutionary as it recommended structural changes in education. ${ }^{42}$ Gradually, the committee's recommendations gained ground, leading to the Education Act of 1979 that in many respects was similar to the Danish Education Act of 1975. It differs, nonetheless, in some areas. For example, in the Faroe Islands, schooling continued to be compulsory for seven years, not nine as in Denmark. According to Petersen, ${ }^{43}$ it also had different

37 Ibid., 108.

38 Petersen (1994).

39 Ibid.

40 Ibid.

41 Erland Viberg Joensen, Daniel Thorleifesen, Guðni Th. Jóhannesson, Jón Th. Thór, and Ils Kolle, “Erhvervs- og næringsliv i tiden ca. 1850-2000," in Naboer i Nordatlanten: Forøerne, Island og Grønland: Hovedlinjer $i$ Vestnordens historie gennom 1000 år, eds. Jon Th. Thór, Daniel Thorleifsen, Andras Mortensen, and Ole Marquardt (Tórshavn: Faroe University Press, 2012), 204-245; Store norske leksikon, “Økonomi og næringsliv på Færøyene,” https://snl.no/\%C3\%98konomi_ og_n\%C3\%A6ringsliv_p\%C3\%A5_F\%C3\%A6r\%C3\%B8yene.

42 Petersen (1994).

43 Ibid., 129-30. 
values and attitudes, especially with respect to upbringing, Christianity and sex education. Petersen points out that the objects clause in the Faroese Education Act of 1979 is more in line with the Norwegian objects clause at the time, especially with respect to its positive attitude towards Christianity. ${ }^{44}$ Pursuant to the Education Act of 1979, the Fólkaskúli consists of a seven-year compulsory primary school and a two-year voluntary continuation school (years 8 and 9). In addition, there was an optional practical and vocational oriented year 10. At the same time, a new overarching curriculum for years one to ten was published. Faroese was compulsory in years one to ten, Danish in years three to nine and English in years six to nine. The curriculum was flexible with a large number of optional subjects in years eight to ten. Years eight and nine had obligatory subjects for 22 hours a week and optional subjects for 12-14 hours (in year ten this was respectively 19-21 and 9-12 hours). The optional subjects were to a large degree vocationally oriented, such as fishing, navigation, agriculture and so on, in addition to more practically oriented subjects, such as music, crafts and domestic economy - as was more the case in Norway after the introduction of nine-year compulsory schooling in 1969. However, according to Petersen, the Faroese curriculum was costly and hard to fulfil. All in all, 1979 was an eventful year in Faroese education history. ${ }^{45}$

Finally, the Education Act of 1992 implemented nine-year compulsory schooling in the Faroe Islands as well. The new Fólkaskúli consists of seven years of primary education and two years of lower secondary education, and an optional year ten. Subsequently, in 1993, the Fólkaskúli adopted its first overall curriculum for years one to nine (ten). A new project-oriented curriculum replaced the earlier flexible vocational programmes in year ten. According to Petersen ${ }^{46}$ the earlier idea of year ten being innovative and designed especially for the Faroese settlement was dropped. However, in accordance with the new regulations, the schools were obliged to develop local curricula in addition to the national ones. ${ }^{47}$ Sigvardsen, who at that time worked for the Directory for Education and Training, travelled across the country to ensure that the schools fulfilled the requirements of the local curriculum. The teachers reported that they experienced this as an additional burden. The 1993 curriculum lasted until 2011. The Education Act of 1992 also introduced a change from a school commission (skolekomisson) to a school board, which involved increased parental representation. ${ }^{48}$

The Education Act of 1997 replaced the Education Act of 1992. Although more than $98 \%$ of the students completed nine years of schooling, the new legislation had a stronger focus on the students' school completion rates. The individual school is now responsible for a tailored education programme in combination with practical work/employment for students in danger of leaving school before completion.

44 Grunnskoleloven 1969 (Oslo: Grøndahl, 1969), \$1.

45 Petersen (1994).

46 Ibid.

47 Sigvardsen (2017).

48 Janus Jensen, "Interview with Nina Volckmar" (March 24, 2017). Jensen has been the Dean at the Department of Education at the University of the Faroe Islands since 2009. Earlier he held a position at the Ministry of Education, Research and Culture. 


\section{After 2005}

Today, the Education Act of 1997, last amended in 2011, regulates Fólkaskúli as a nine-year compulsory comprehensive schooling (not school attendance) and a voluntary year ten. Compulsory schooling starts in August the year the child turns seven and ends after nine years of teaching, or at the latest July 31, the year the child turns 17. In some municipalities, students can start school at age six (year 0 as in Denmark). The Education Act of 1997 (2011) places greater emphasis on student participation than previously. ${ }^{49}$

The Faroe Islands received their PISA shock in 2006 and have since evaluated the PISA results and implemented measures to raise their results..$^{50}$ Bearing this in mind, the government introduced national tests for years four and six in 2009, and since 2012, a competence centre has assisted the schools in improving their results. However, according to Claus Reistrup, ${ }^{51}$ the relevance of the PISA test for Faroese education and the Faroese society is a heatedly discussed topic. Many question whether participating in the PISA test and national tests has any benefit for what they want in the Faroese society. In the 2017/2018 school year, the national tests were cancelled due to technological problems. This was followed by a discussion about the purpose of national tests in the legislative assembly, and the national tests have not yet been re-introduced. ${ }^{22}$

Along with the 2011 legislation, the Faroese Fólkaskúli was given a new national curriculum. According to Jensen, ${ }^{53}$ the new curriculum is a management-by-objectives curriculum strongly inspired by the Norwegian curriculum from 2006 (National Curriculum for Knowledge Promotion in Primary and Secondary Education and Training). The main subjects in the Fólkaskúli are Christianity, Faroese, mathematics and sports. The students have these subjects in all school years. They then have Danish in years three to nine and English in years four to nine. ${ }^{54}$ Christianity is still listed first in the curriculum, reflecting the continued strong position of Christianity in the Faroese community. Other subjects are history, science, geography, local studies and crafts. There is a wide range of subjects to choose between in years eight and nine, and especially in year ten, with many practical and vocationally-oriented subjects. The idea from the very beginning has been to have one overriding curriculum all the way from kindergarten to upper secondary education, but this did not materialise. The kindergarten years still has no national curriculum.

More than half of the students choose to take year ten instead of directly entering upper secondary education (miðnámsútbúgving). The percentage of students

49 Løgtingslóg nr. 125 frá 20. Juni 1997 um fólkaskolan, sum seinast broytt viðløgtingslóg nr. 67 frá 26. mai 2011.

50 See public reports from 2006, 2009 and 2016.

51 Claus Reistrup, "Interview with Nina Volckmar" (March 29, 2017). Reistrup is a former teacher in upper secondary education in Tórshavn, appointed by the Ministry of Education, Research and Culture 1992-2013, and from 2013-2015 a consultant responsible for the reports on the PISA results.

52 Information from Kjartan Gaard Sleire October 2018. Sleire is a teacher in the Faroe Islands and research fellow at the University of the Faroe Islands.

53 Jensen (2017).

54 See the Ministry of Education Research and Culture’s webpages: "Námsætlanir: Fólkaskúlí,” http:// www.namsaetlanir.fo/folkaskuli; "Námsætlanir: Gymnasialt Miðnám," http://www.namsaetlanir.fo/ midnam; “Námsætlanir. Yrkismiðnám," http://www.namsaetlanir.fo/yrkismiðnam 
attending year ten in 2016/2017 was 63 per cent. ${ }^{55}$ Due to the popularity of year ten, the Fólkaskúlaráðið (which is an advisory committee of all partners with an interest in Fólkaskúlin) in 2016 presented a report to improve the subject curricula for year ten.

\section{Upper secondary education}

The historical development of upper secondary education in the Faroe Islands, as in other countries, is difficult to trace. One reason is that primary education, on which secondary education builds, varied locally as to the number of years children attended school and the schools availability. Another reason is that secondary education in the Faroe Islands, as elsewhere, depended for a very long time on private initiatives. Petur Jacob Sigvardsen, an educational official, also points to the fact that the somewhat unclear regulation of education as a joint responsibility between Denmark and the Faroe Islands has promoted a mixture of private, municipal and stateowned schools. ${ }^{56}$ Moreover, at the upper secondary level, the Danish influence was far stronger than at the primary and lower secondary levels and this continues to be the case. Considering the above factors, I will give a brief overview of the development towards a comprehensive education system in upper secondary education, mainly from World War II and onwards.

I use the term upper secondary education as the level between primary education and tertiary education or between primary education and (skilled) work. Thus, secondary education starts at age 14 after the introduction of seven years of compulsory education, and at age 16 after the introduction of nine (ten) years of compulsory education. When compulsory education was extended to nine (ten) years in 1992, years eight and nine (ten) were called lower secondary education, and at the same time a more streamlined qualifying upper secondary education was developed. Today the most common terms in use in the Faroe Islands are Folkeskúli for primary and lower secondary education and Midnám for upper secondary education. According to Sigvardsen, ${ }^{57}$ the term midnám was his idea, as nám refers to the transition from sandy beach to grassland, and mid to something in the middle. Now, the new and monumental school building at the upper secondary level, Glasir Marknagil, stands in the outskirts of Tórshavn, and the nameplate outside the school states that this is Glasir, Tórshavn College. Glasir is the name of a new construction/institution, unifying general studies, the business school and the technical school under the same roof, and I understand that the use of "college" in the name indicates that the school also offers education beyond the upper secondary level. ${ }^{58}$ In Norse mythology, Glasir is a beautiful tree with golden leaves located in the realm of Asgard outside the doors of Valhalla ${ }^{59}$ No doubt, this is the Faroese people's new pride.

Until the establishment of the two-year realskole in Tórshavn in 1861, there was no real education past the Almueskole in the Faroe Islands. At first, the realskole was

55 Statbank, "UV02010 Public school, number of pupils by school and class (2005/2006-2018/2019)," https://statbank.hagstova.fo/pxweb/en/H2/H2__UV__UV02/fs_ntalsk.px/?rxid=387fc6a9-d664-464f-aa62-a4d293abcd01.

56 Sigvardsen (2017).

57 Ibid.

58 Glasir, "Glasir Tórshavn College," https://www.glasir.fo/english/.

59 Glasir, "First day of school for Glasir, Tórshavn College," https://www.faroeislands.fo/the-big-picture/news/first-day-of-school-for-glasir-t\%C3\%B3rshavn-college/. 
only for boys; girls could attend from 1892 onwards. From 1910, the school held qualification examinations for higher education. The Danish government opposed several Faroese attempts to establish their own gymnasium as it argued that the population in the Faroese Islands was too small and that the students could easily pursue their education in Denmark. In the 1930s, the attitude to locating the state upper secondary education in the Faroe Islands changed positively, and in 1937, the Faroese authorities managed to establish a two-year student course in Torshavn. However, the educational structure was Danish, and due to the need for boarding, it was very expensive for the students who lived outside town. The Faroese Parliament paid all expenses. The further development of upper secondary education came to a stop during World War II. In 1959, the two-year student course became a three-year gymnasium. The Education Act of 1962 ensured a three-year gymnasium offering studies in languages and mathematics, whilst social science was added in 1972 and science in 1973, all in Tórshavn. ${ }^{60}$

In the period after World War II and until more governmental regulations in the 1990s, a number of vocational schools were established, some more permanent than others. There are too many to mention them all. Some selected and important schools were: Føroya Navigation School (1949), Tórshavn Technical School (1935/1956), Tórshavn Nursing School (1960), Føroya Machine School in Tórshavn (1964), Tórshavn Commercial School (1983), Køllafiørdur Agriculture School (1986) and the Fishery School in Vestmanna (1989). As Sigvardsen points out, some were privately funded, some were funded by the local authority and some by the Danish government. ${ }^{61}$ However, gradually a more coordinated and centralised system was established. The Faroese Blå Betcenkning from 1974 regulated further expansion and progressive coordination of all vocational training in the Faroe Islands. One aim was to decentralise vocational training in such a way that the students could take the first basic course while living at home.

The coordination of all upper secondary education began during the 1980s, with two reports being particularly important: Midnámsútbúgvingar from 1985 provided guidelines for the implementation of general upper secondary education (young people 16-19 years of age), and Álit um ástødisútbúgvingar, from 1990, which proposed structural changes in vocational education and training.

In the early 1990s, the Faroe Islands experienced an economic crisis with high unemployment, heavy debt and considerable emigration. According to Claus Reistrup, ${ }^{62}$ the number of apprenticeships dropped from 400 to 58 over the course of one year, and the old system of serving apprenticeships with employers collapsed. This led to new reforms in vocational education and training, such as a common basic course (SIT) before entering the vocational courses. The 1990s were generally turbulent, and upper secondary education was subject to continuous reforms. First, new legislation regulated the courses and levels within upper secondary education, such as in general education (ST and HF), technical schools (HT), business schools (HH) and fishery schools (HIV). By the end of the 1990s, some of these regulations were unified into three types of legislation, one for vocational programmes, one

60 Petersen (1994).

61 Sigvardsen (2017).

62 Reistrup (2017). 
for administration, commerce and office programmes, and one for technical subjects. For general studies upper secondary education, the Education Act of 1995 was especially important, regulating general studies upper secondary education for the next 20 years. ${ }^{63}$ The main impression is that upper secondary education in the Faroe Islands, at least until quite recently, followed both the Danish organisation of upper secondary education and its content. This is especially evident in the general studies course. According to Reistad, ${ }^{64}$ a small country like the Faroe Islands has neither the money nor the population to develop an education system all on its own. It needs to borrow from other countries.

Next, the Education Act of 2012 for the general studies unified all general studies education under one umbrella, gymnasialar miðnámsútbúgving, with altogether six equal directions qualifying for higher education and university admittance: búskaparbreyt (economic specialisation), hugbreyt (language specialisation), nátttúrubreyt (science specialisation), tilfeingisbreyt (fishery specialisation), tøknibreyt (technical specialisation), and fyrireikingarbreyt (two-year general studies education for students over 18 years of age). At the same time, all vocational education and training were joined under one umbrella as yrrkismiðnám, with altogether six technical directions: maskinsmiðútbúgving (machine specialisation), smiðjuútbúgving (smithy specialisation), elektrikaraútbúgving (electrician specialisation), timburútbúgving (carpentry specialisation), hárfríðkanarútbúgving (hairdressing specialisation) and bilsmiðútbúgving (auto-mechanical specialisation). Finally, in 2015, the government unified and amended all legislation regulating upper secondary education. ${ }^{65}$ This means that Faroese upper secondary education now has two main tracks, one offering general studies education qualifying for admission to higher education, and one vocational or technical education qualifying students primarily for the labour market. ${ }^{66}$ The Faroe Islands' "new pride," Glasir Tórshavn College, opened in August 2018 and is the largest college and upper secondary school in the islands. Glasir offers general studies education, vocational training, continuous professional development (CPD), further education and higher education. A world-renowned architect, Bjarke Ingels, has designed the 19,500 square metre monumental building.

In 2011, the Ministry of Education, Research and Culture established a net portal, Námsœtlanis. ${ }^{67}$ Initially, this included only the Fólkaskúli, but in 2012, upper secondary education was also included, and eventually, kindergarten as well. The net

63 According to Reistrup the Education Act 1995 is based on a report he wrote.

64 Reistad (2017).

65 Upper secondary education is regulated by four Acts, one for vocational education and training (Løgtingslóg nr. 94 frá 29. desember 1998 um yrkisútbúgvingar, sum seinast broytt við løgtingslóg nr. 29 frá 30. apríl 2015), one for administration, commerce and office (Løgtingslóg nr. 107 frá 29. desember 1998 um støðisútbúgving innan fyrisitingar-, handils- og skrivstovuøkið, sum broytt við løgtingslóg nr. 32 frá 30. apríl 2015), one for technical education (Løgtingslóg nr. 41 frá 23. apríl 1999 um støðisútbúgving innan tøkni, sum seinast broytt við løgtingslóg nr. 35 frá 30. apríl 2015) and one for general studies upper secondary education (Løgtingslóg no. 62 frá 15. mai 2012 um gymnasialar miðnámsútbúgvingar, sum seinast broytt við løgtingslóg nr. 140 frá 18. desember 2015).

66 Ministry of Education, Research and Culture, "Government of the Faroe Islands," http://www.government.fo/the-government/ministries/ministry-of-education-research-and-culture/.

67 Ministry of Education, Research and Culture, "Námsætlanir og stevnumið til dagstovnar, fólkaskúla og midnám," http://www.namsaetlanir.fo. 
portal contains all relevant legislation, curricula and public announcements. Even though the curricula for primary, lower secondary education and upper secondary education are presented on this site, there is no overriding curriculum from years one to twelve.

\section{Faroese self-determination in education - a discussion}

To what extent can a small society such as the Faroe Islands decide over their own school development, and what factors have had a promoting or inhibiting influence on this development? To obtain a better understanding of the complexity of these questions I will first take a closer look at the changing modes of governing structures, the fluctuations in economic development and political constellations as (decisive) contextual factors. I will then present a summary that analyzes the winding path to a comprehensive education system using the terms policy diffusion and policy borrowing.

\section{Governing structures, economic development and political constellations}

One determining factor is primarily the changing mode of governance structures. Until the Home Rule Act of 1948, since the introduction of compulsory education in the Danish-Norwegian Kingdom in 1739, education in the Faroe Islands was formally subordinate to Danish legislation. However, due to cultural differences, a strained economy and geographical challenges, the introduction of compulsory schooling was more challenging, met with greater resistance and took longer than in both Denmark and Norway. At the same time, and for the same reasons, the Faroe Islands continued their own home-education system that lasted until the first Faroese Education Act of 1854 and beyond. The Faroese home-education system had its parallels to the Danish and Norwegian ambulatory schools. However, home education in the Faroe Islands was perhaps more adapted to the Faroese culture and mode of living than was the case in Denmark and Norway and therefore was more persistent.

The Home Rule Act of 1948 made education a Faroese responsibility and the Faroese themselves could begin to develop their own education system. The first step was the introduction of seven-year compulsory comprehensive schooling as a basis for further education in 1962, and next the final enactment of nine years of compulsory schooling in 1992. Both came a long time after the implementation of similar schooling in Denmark and Norway. Starting in 1959 and up to the millennium, school committees were continuously working to find the Faroese path towards a comprehensive education system. However, during this period the Faroese had a firmer hand in the development of primary education than in lower secondary and upper secondary education. Above primary level, the Faroese tended to take advantage of the Danish education system by sending their students to Denmark for further education, or by implementing the Danish curriculum in the Faroe Islands. Moreover, as we have seen, in 1979 the Faroe Islands looked to Norway instead of Denmark to find an objects clause that protected Christianity's strong position in the Faroe Islands. The situation was the same in 2011, when the Faroese were inspired by the Norwegian Curriculum of 2006.

Until the 1970s and 1980s, education at the upper secondary level was characterised mainly by private vocational schools. Only in the last decades of the twentieth 
century did more coordinated legislation for upper secondary education emerge. The Takeover Act of 2005 was a watershed in this respect, and in 2015, all upper secondary education was regulated under the same legislation. At present, upper secondary education in the Faroe Islands has two main courses, one offering general studies education qualifying for admission to higher education and the other offering vocational or technological education qualifying for the labour market.

Another important decisive factor in the development of Faroese education is the economic situation. As mentioned above, fisheries emerged as the dominant commercial sector during the twentieth century and added income to a rather sluggish treasury. Increased revenue enabled both improvement of the road network and the construction of new schools, which was a prerequisite for introducing seven-year compulsory education in 1962 and the further developments in the following decades. However, the dominant role of the fisheries in the Faroese economy has made the Faroe Islands very vulnerable to fluctuations in catches and prices. In 1987, the fisheries industry suffered a downturn, both due to falling prices and because the Faroe Islands had limited fishing rights in other countries' waters. This resulted not only in bankruptcies among fishing boat owners, breeders and the fish processing industry, but also in the shipbuilding industry, service industry and retail trade. ${ }^{68}$ Once again, in the mid-1990s, the Faroe Islands suffered a severe economic crisis which led to substantial emigration to Denmark. After the recovery in the late 1990s, the economy has gradually improved and many have returned. ${ }^{69}$ The Faroese business sector has gradually become more diversified. However, the fishing industry is still the major economic catalyst and is in constant development. Today it covers various areas, spanning pelagic and demersal fisheries and the fish processing industry. The Faroese fish farming industry is one of the most sustainable and profitable aquaculture industries in the world. Fishing and its related industries account for around 20 per cent of the gross annual value added to the Faroese economy. ${ }^{70}$

The 2008 global financial crisis also affected the Faroese economy, and the unemployment rate rose from 1.5 per cent in 2007 to 7.4 per cent in 2010. However, the Faroese economy has since stabilised, and in recent years it has performed quite well. The unemployment rate in 2017 was down to 2.0 per cent. ${ }^{71}$ Some have even referred to the Faroe Islands as the "super economy" of the north, mainly due to high salmon and aquaculture fish prices. ${ }^{72}$ Investments have been made in extensive road and tunnel projects, in the salmon industry and in schools and kindergartens. There are signs of a consumer boom with increased sales of new cars, renovation projects and the construction of new homes. Indeed, there are warning signs about an overheating economy. However, the Danish government still subsidises the Faroe Islands with a block grant, which in 2017 was frozen at DDK 642 million (EUR 86 million).

68 Store norsk leksikon, “Økonomi og næringsliv på Færøyene." https://snl.no/\%C3\%98konomi_ og_n\%C3\%A6ringsliv_p\%C3\%A5_F\%C3\%A6r\%C3\%B8yene

69 Encyclopædia Brittannica, "Faroe Islands," https://www.britannica.com/place/Faroe-Islands-Atlantic-Ocean

70 The official gateway to the Faroe Islands, "A Dynamic and Resilient Economy," https://www.faroeislands.fo/economy-business/economy/

71 Ibid.

72 Bent Højgaard Sørensen, "Dette er Nordens 'superøkonomi”' https://e24.no/utenriks/fisk/detteer-nordens-superoekonomi/24007055 
The subsidy constitutes 3.3 per cent of the current Faroese GDP, compared to 11.2 per cent in 2000. This means that the national budget was funded at 13 per cent in 2017, compared to 28.7 per cent in $2000 .^{73}$

The Takeover Act and the improved economic climate have made it possible to have the large-scale investments in education that we have witnessed in the past decade. The Glasir complex is a particularly important example of this.

It is clear that the social democratic parties have been the driving political force in the development and extension of comprehensive education in the Scandinavian countries after World War II until the late 1980s. ${ }^{74}$ Most researchers agree that since the late 1980s, the Nordic countries have experienced political pressure from global neoliberal right wing education policy. ${ }^{75}$ However, the role of the social democratic parties in the neoliberal market-led education policy in Scandinavia has been contested. ${ }^{76}$ Volckmar and Wiborg claim that "the Swedish Social Democrats have given greater credence to market forces for improving education, whereas the Social Democrats in Denmark and Norway have been more reluctant in this regard." ${ }^{\prime 7}$

How does this coincide with the development in the Faroe Islands? They have a multiparty system where normally none of the many parties gains enough power on its own. Thus, coalition governments are the norm. Moreover, the party-political landscape in the Faroe Islands is far more blurred than in the Scandinavian countries, as the dividing line is not only between the right-wing and the left-wing parties, but also between those arguing for complete separation from Denmark and those arguing for a continued union. I have argued that the Social Democrats were the leading party during the implementation of the seven-year compulsory education in the Faroe Islands in 1962. However, the Faroese political landscape is too blurred for a foreigner to understand which role the Social Democrats have played in education policy processes in a neoliberal educational context. In recent decades the Faroese government seems to alternate between a right-wing coalition government and a left-wing coalition government almost from one election to the next. Nevertheless, since the Takeover Act of 2005, the development of comprehensive education in the Faroe Islands seems to support the overall impression of consensus.

\section{Faroese resistance}

This article has described the development of comprehensive education in the Faroe Islands and at the same time attempted to explain the governance approaches and influences from Denmark and Norway. However, it is also important to explicitly point out those areas where the Faroe Islands opposed the Danish development and what they have borrowed from Norway. Most striking is the resistance to compulsory schooling and their persistent defence of home schooling. The Faroese opposed what

73 The official gateway to the Faroe Islands, "A Dynamic and Resilient Economy," https://www.faroeislands.fo/economy-business/economy/

74 Volckmar and Wiborg (2014); Volckmar (2016).

75 Ulf Blossing, Gunn Imsen, and Lejf Moos, The Nordic Education Model: 'A School for All' Encounters Neo-Liberal Policy (Dordrecht: Springer Netherlands, 2014); Alfred O. Telhaug, Odd A. Mediås, and Petter Aasen, "The Nordic Model in Education: Education as Part of the Political System in the Last 50 Years," Scandinavian Journal of Educational Research 50, no. 3 (2006).

76 Volckmar and Wiborg (2014).

77 Ibid., 127. 
they experienced as unnecessary education in relation to the Faroese mode of living at that time. Eventually, the Home Rule Act and economic growth gave the policymakers the opportunity to take the necessary steps towards a compulsory comprehensive education system. Moreover, we see that for the same reason and to a larger extent than Denmark and Norway, the Faroese emphasise practical and vocational subjects in the curriculum for years eight and nine (and ten).

The 1979 Faroese Education Act opted for the Norwegian objects clause ${ }^{78}$ rather than the Danish clause. One explanation might be that the Social Democrats, the Independence Party and the Republican Party were in charge of the educational development at the time and thus legitimatised looking to Norway rather than to Denmark for inspiration. Another and perhaps more plausible explanation is that the Norwegian objects clause at that time was still founded on Christian values while the Danish version had removed its traditional anchoring in Christian values in the 1975 Education Act $^{79}$. Christianity is still mentioned first of the subjects in the Faroese Fólkaskúli curriculum, which reflects the strong position of Christianity in the Faroese community.

Finally, the Faroese considered that their participation in PISA was largely negative for two reasons. Firstly, it did not measure what was important for the Faroese, and secondly, there was a lack of relevance to local concerns.

\section{Policy diffusion and policy borrowing}

Policy diffusion as geographical clustering between neighbouring countries seems appropriate when the aim is to obtain a better understanding of and explain the Faroese case.$^{80}$ Despite some political, economic and cultural differences, the Faroe Islands' historical and geographical proximity to Norway and Denmark made it convenient to look to these two countries for solutions, even when the Faroe Islands formally took over the responsibility for education. One obvious dimension is the lack of capacity. ${ }^{81}$ Due to the Faroe Islands' low population and the lack of capacity in the Faroese political administration, the Faroe Islands had to look for ready-made solutions. The political circumstances and the country's strong affiliation to Denmark meant that it was opportune to first adopt their solutions directly and gradually adapt Danish solutions to Faroese conditions. These borrowing processes are seldom explicitly acknowledged and must be found through analyses and/or additional sources. Florian Waldow, Professor of comparative and international education refers to such non-explicit policy borrowing processes as silent borrowing. The adoption of the Norwegian objects clause for the Faroese Education Act of 1979 might serve as an example. This was not explicitly acknowledged in the written sources available, however, it was acknowledged in an interview with a former school bureaucrat. ${ }^{82}$ The process of policy diffusion does not necessarily imply adoption of the entire school reform, but rather adaption of some parts of it.

78 The objects clause is the first paragraph in the Education Act, containing the overarching mission statement for all the activities in school.

79 Karl-Arne Korseberg, "Skolens verdigrunnlag. En historisk-komparativ analyse av skolens formålsparagraf i Danmark og Norge" (In process and unpublished $\mathrm{PhD}$ research, Norwegian University of Science and Technology).

80 Shipan and Volden (2012).

81 Ibid.

82 Sigvardsen (2017). 
In general, we can say that the adoption of extended compulsory comprehensive schooling, the lowering of the school-start age, implementation of national tests and reforms in upper secondary education in the Faroe Islands came late compared to its neighbouring Nordic countries. According to research on policy borrowing, the late adoption can be explained by the epidemiological model of global dissemination, addressing the temporal dimension of local adaption of global education policy. ${ }^{83}$ This model distinguishes between early and late adopters of an innovation. In the early stages, adopters make explicit references to lessons learned from other educational systems, especially those that they are specifically seeking to emulate. During the phase of explosive growth, however, more systems adopt a reform. They do so because they are afraid of being left behind and labelled old-fashioned. Late adoption, according to this model, should be interpreted as an orientation statement made by policymakers to denote their geopolitical affiliation with a larger, modern educational space. ${ }^{84}$ Explicit traces of transnational policy borrowing seem to disappear. Late adopted reforms are more vaguely explained as adapting to what is considered to be "global education" and "international standards."

In this context, the new construction/institution of Glasir Marknagil, unifying general studies, the business school and the technical school under the same roof, is particularly interesting. Even if this is a new construction and it is not yet clear what it will become, it is tempting to see this as an adaption of the current global education policy. ${ }^{85}$ Improved economic conditions have enabled effective collaboration between education policymakers and business actors.

At the same time, it seems that in some areas the Faroe Islands have found their own way. The 2017 Act on the Management of Marine Resources demonstrates Faroese resistance and independence in recent years, probably linked to its strong economic growth. This Act represents a major reform of national fisheries management and states that "all living marine resources in Faroese waters are the property of the people of the Faroe Islands, and as such, fishing licences may never become private property, neither by law nor practice. Furthermore, fishing licences cannot be traded directly between private buyers. To change hands, licenses must go through a public auction." ${ }^{\prime 6}$ Compared to other fishing nations, the Faroes Islands seem more protective of the desire to keep their resources in Faroese hands. Thus, Glasir seems to be a Faroese construction adapted to the Faroe Islands' flourishing economy and commercial interests, as well as an adaptation of global education policy and international standards. The Faroese economy has given the Faroe Islands greater scope for independence and latitude. To quote Steiner-Khamski, "[p]olicy borrowing is never wholesale, but always selective and, by implication, reflects the 'socio-logic' or context-specific reasons for receptiveness." 87

83 Steiner-Khamsi (2010).

84 Ibid., 333-34.

85 Glasir, "The new Glasir Education Centre in Torshavn - a perfect example of how open space and new learning formats can change education," https://www.tmf-dialogue.net/the-new-glasir-education-centre-in-torshavn-a-perfect-example-how-open-space-and-new-learning-formats-canchange-education.html

86 The Government of the Faroe Islands, "The Faroese Parliament Passes Fisheries Reform," https:// www.government.fo/en/news/news/the-faroese-parliament-passes-fisheries-reform/2018.

87 Steiner-Khamsi (2014), 156. 


\section{Acknowledgements}

My motivation for writing this article on Faroese education came through my participation in the research project Valuing the past, sustaining the future: Education, knowledge and identity across three generations in coastal communities; a comparative approach, in which the Faroe Islands were included. The research project is led by Anne Trine Kjørholt, Department of Education and Lifelong Learning, Norwegian University of Science and Technology. In the spring 2017 I spent two months at the University of the Faroe Islands in Tórshavn. 


\section{References}

Appel, Charlotte, and Ning de Coninck-Smith, eds., Dansk Skolehistorie, Vol. 1-5. Aarhus: Aarhus Universitetsforlag, 2013-2015.

Appel, Charlotte, and Morten Fink-Jensen. Da loereren holdt skole. Tiden før 1780. Dansk Skolehistorie, edited by Charlotte Appel and Ning de Coninck-Smith. Vol. 1. Aarhus: Aarhus Universitetsforlag, 2013.

Blossing, Ulf, Gunn Imsen, and Lejf Moos. The Nordic Education Model: 'A School for All' Encounters Neo-Liberal Policy. Dordrecht: Springer Netherlands, 2014.

Encyclopædia Brittannica, "Faroe Islands." https://www.britannica.com/place/Faroe-Islands-Atlantic-Ocean (accessed May 15, 2018).

Gjerløff, Anne Katrine, and Anette Faye Jacobsen. Da skolen blev sat i system. 18501920. Dansk Skolehistorie, edited by Charlott Appel and Ning de Coninck-Smith. Vol. 3. Aarhus: Aarhus Universitetsforlag, 2014.

Gjerløff, Anne Katrine et al. Da skolen blev sin egen. 1920-1970. Dansk Skolehistorie, edited by Charlotte Appel and Ning de Coninck-Smith. Vol 4. Aarhus: Aarhus Universitetsforlag, 2014.

Glasir, "First day of school for Glasir, Tórshavn College." https://www.faroeislands. fo/the-big-picture/news/first-day-of-school-for-glasir-t\%C3\%B3rshavn-college/ (acessed March 12, 2019).

Glasir, "Glasir Tórshavn College." https://www.glasir.fo/english/ (accessed March 1, 2018).

Glasir, "The new Glasir Education Centre in Torshavn - a perfect example of how open space and new learning formats can change education." https://www.tmf-dialogue. net/the-new-glasir-education-centre-in-torshavn-a-perfect-example-how-openspace-and-new-learning-formats-can-change-education.html (accessed February 8 , 2019).

Grunnskoleloven 1969. Lov av 13. Juni 1969 om grunnskolen. \$1. Oslo: Grøndahl, 1969.

Imsen, Gunn and Nina Volckmar. "The Norwegian School for All: Historical Emergence and Neoliberal Confrontation." In The Nordic Education Model. 'A School for All' Encounters Neo-Liberal Policy, edited by Ulf Blossing, Gunn Imsen and Lejf Moss, 35-55. Dordrecht: Springer Netherlands, 2014.

Jacobsen, Elin S., Sigdriður Jörundsdóttir, and Daniel Thorleifsen, "Skole og uddannelse." In Naboer i Nordatlanten: Forøerne, Island og Grønland: Hovedlinjer $i$ Vestnordens historie gennom 1000 år, edited by Jón Th. Thór, Daniel Thorleifsen, Andras Mortensen and Ole Marquardt, 297-360, Thórshavn: Faroe Univesity Press, 2012.

Jensen, Janus. "Interview with Nina Volckmar." (March 24, 2017).

Joensen, Erland Viberg, Ole Marquardt, and Jón Th. Thór, "Erhvervs- og næringsliv i tiden ca. 1550-1850." In Naboer i Nordatlanten: Feerøerne, Island og Grønland: Hovedlinjer $i$ Vestnordens historie gennom 1000 år, edited by Jon Th. Thór, Daniel Thorleifsen, Andras Mortensen, and Ole Marquardt, 162-203, Tórshavn: Faroe University Press, 2012.

Joensen, Erland Viberg, Daniel Thorleifesen, Guðni Th. Jóhannesson, Jón Th. Thór, and Nils Kolle, "Erhvervs- og næringsliv i tiden ca. 1850-2000." In Naboer i Nordatlanten: Færøerne, Island og Grønland: Hovedlinjer $i$ Vestnordens historie gennom 1000 år, edited by Jon Th. Thór, Daniel Thorleifsen, Andras Mortensen, and Ole Marquardt, 204-45, Tórshavn: Faroe University Press, 2012. 
Korseberg, Karl-Arne. "Skolens verdigrunnlag: En historisk-komparativ analyse av skolens formålsparagraf i Danmark og Norge." Ongoing PhD research, Norwegian University of Science and Technology.

Larsen, Christian, Erik Nørr, and Pernille Sonne. Da skolen tog form: 1780-1850. Dansk Skolehistorie, edited by Charlotte Appel and Ning de Coninck-Smith. Vol. 2. Aarhus: Aarhus Universitetsforlag, 2013.

Løgtingslóg nr. 62 frá 29. desember 1998 um yrkisútbúgvingar, sum seinast broytt við løgtingslóg nr. 29 frá 30. april 2015 [Act no. 62, December 29, 1998 relating toVocational Education, last ammended April 30, 2015].

Løgtingslóg nr. 94 frá 15. mai 2012 um gymnasialar miðnámsútbúgvingar, sum seinast broytt við løgtingslóg nr. 140 frá 18. desember 2015 [Act no. 94, May 15, 2012 relating to Upper Secondary Education, last ammended December 18, 2015].

Løgtingslóg nr. 125 frá 20. juni 1997 um fólkaskolan, sum seinast broytt viðløgtingslóg nr. 67 frá 26. mai 2011 [Act no. 125, June 20, 1997 on Primary Education, last ammended May 26, 2011].

Ministry of Education, Research and Culture. "Government of the Faroe Islands." http://www.government.fo/the-government/ministries/ministry-of-education-research-and-culture/ (accessed March 8, 2017).

Ministry of Education, Research and Culture. "Námsætlanir og stevnumið til dagstovnar, fólkaskúla og miðnám. [Curriculum and objectives for day-care centres, primary education and upper secondary education]." http://www.namsaetlanir. fo (accessed March 22, 2018).

Ministry of Education, Research and Culture. "Námsætlanir. Fólkaskúlí.[Curriculum for Primary Education].” http://www.namsaetlanir.fo/folkaskuli (accessed March 17, 2017).

Ministry of Education, Research and Culture. "Námsætlanir. Gymnasialt miðnám [Curriculum for General Upper Secondary Education]." http://www.namsaetlanir.fo/midnam (accessed March 17, 2017).

Ministry of Education, Research and Culture. "Námsætlanir. Yrkismiðnám [Curriculum for Vocational Education and Training].” http://www.namsaetlanir.fo/ yrkisnam (accessed March 17, 2017).

Petersen, Ludvig. Skole på Førøerne i 1000 år: En skolehistorisk håndbog. Tórshavn: Eget forlag i samarbeid med Selskabet for Dansk Skolehistorie og Føroya Lærarskúla, 1994.

Reistrup, Claus. "Interview with Nina Volckmar” (March 29, 2017).

Shipan, Charles R., and Craig Volden. "Policy Diffusion: Seven Lessons for Scholars and Practitioners.” Public Administration Review 72, no. 6 (2012), 788-96.

Sigvardsen, Petur Jacob. "Interview with Nina Volckmar" (March 7 and 9, 2017).

Sroka, Wendelin. "Faroe Islands." In The Education Systems of Europe, Global Education Systems, edited by Wolfgang Hörner et al., 249-250. Dordrecht: Springer Netherlands, 2015. DOI 10.1007978-3-319-07473-3_15.

Statbank. "UV02010 Public school, number of pupils by school and class (2005/20062018/2019)." https://statbank.hagstova.fo/pxweb/en/H2/H2_UV_UV02/fs_ntalsk. px/?rxid=387fc6a9-d664-464f-aa62-a4d293abcd01 (accessed February 5, 2019).

Steiner-Khamsi, Gita. "Comparison and Context: The Interdisciplinary Approach to the Comparative Study of Education." Current Issues in Comparative Education 16 , no. 2 (2014a), 34-42. 
Steiner-Khamsi, Gita. "Cross-National Policy Borrowing: Understanding Reception and Translation." Asia Pacific Journal of Education 34, no. 2 (2014), 153-76.

Steiner-Khamsi, Gita. "New Directions in Policy Borrowing Research." Asia Pacific Education Review 17, no. 3 (2016), 381-90.

Steiner-Khamsi, Gita. "The Politics and Economics of Comparison." Comparative Education Review 54, no. 3 (2010), 323-42.

Store norskeleksikon. “Økonomi og næringsliv på Færøyene.”https://snl.no/\%C3\%98konomi_og_n\%C3\%A6ringsliv_p\%C3\%A5_F\%C3\%A6r\%C3\%B8yene (accessed April 10, 2018).

Sørensen, Bent Højgaard. “Dette er nordens 'superøkonomi”’ E24. https://e24.no/utenriks/fisk/dette-er-nordens-superoekonomi/24007055 (accessed April 4, 2018).

Telhaug, Alfred Oftedal, Odd Asbjørn Mediås, and Petter Aasen. “The Nordic Model in Education: Education as Part of the Political System in the Last 50 Years." Scandinavian Journal of Educational Research 50, no. 3 (2006), 245-83.

Thomassen, Arnfinnur. Ferøsk i den foerøske skolen. Fra århundredskiftet til 1938. Odense: Udgivelsesudvalgets samling af studenterafhandlinger, 1985.

Thór, Jón Th., Jóan Pauli Joensen and Daniel Thorleifsen, "Nationalisme og nationsdannelse i 1800- og 1900-tallet." In Naboer i Nordatlanten: Forøerne, Island og Grønland, edited by Jon Th. Thór, Daniel Thorleifsen, Andras Mortensen, and Ole Marquardt, 395-465. Tórshavn: Faroe University Press, 2012.

The Government of the Faroe Islands. "The Faroese Parliament Passes Fisheries Reform." https://www.government.fo/en/news/news/the-faroese-parliament-passes-fisheries-reform/ (accessed September 25, 2018).

The Government of the Faroe Islands. "Home Rule Act of the Faroe Islands 1948." http://www.government.fo/the-government/the-home-rule-act/ (accessed January 16, 2018).

The Government of the Faroe Islands. "Takeover Act of the Faroe Islands 2005." http://www.government.fo/foreign-relations/constitutional-status/the-takeover-act/ (accessed January 16, 2018).

The official gateway to the Faroe Islands. "A Dynamic and Resilient Economy." https:// www.faroeislands.fo/economy-business/economy/ (accessed April 6, 2018).

University of the Faroes Islands. "University of the Faroe Islands." https://www.setur. fo/en/ (accessed September, 2018).

Volckmar, Nina, ed. Utdanningshistorie: Grunnskolen som samfunnsintegrerende institusjon. Oslo: Gyldendal Akademisk, 2016.

Volckmar, Nina, and Susanne Wiborg. "A Social Democratic Response to MarketLed Education Policies: Concession or Rejection?" In The Nordic Education Model: 'A School for All' Encounters Neo-Liberal Policy, edited by Ulf Blossing, Gunn Imsen and Lejf Moss, 117-31. Dordrecht: Springer Netherlands, 2014.

Waldow, Florian. "Undeclared Imports: Silent Borrowing in Educational Policy-Making and Research in Sweden." Comparative Education 45, no. 4 (2009), 477-94. 